\title{
The Impact of Professional Development on Beginning Teachers' Practices in One Secondary School
}

\author{
Marjorie Hinds \\ University of Ottawa \\ Marie-Josée Berger \\ University of Ottawa
}

\begin{abstract}
A case study was conducted in 2004-2005 on the professional development experiences of beginning teachers (1-5 years of experience) in an Ontario, Canada secondary school (Grades 7-12) and the impact of those experiences in improving their practices. For comparative purposes, the study included the perspectives of administrators from the same school on the impact of professional development on these teachers. The findings revealed that the literacy training program was successfully implemented at the school and positively affected beginning teachers' knowledge, instructional strategies, and planning practices. Other findings indicated that beginning teachers needed subject content and instructional strategies, ongoing mentoring, and skills in both classroom management and mapping the curriculum. Based on the findings of the study, a new framework for professional development is suggested. A number of recommendations propose ways of connecting research, policy and practice that could ultimately improve the effectiveness of professional development programs for beginning teachers.
\end{abstract}

Key words: teacher professional development, beginning teacher, adult learning, self-efficacy, collective efficacy, supervision, organizational policies and culture

Marjorie Hinds, $\mathrm{PhD}$ is a retired principal with over 30 years experience in the teaching profession. Hinds currently mentors Education graduate students, conducts research on teacher professional development in Ontario secondary schools, and serves on the Board of Directors of the Council on Aging of Ottawa.

Marie-Josée Berger is Dean of the Faculty of Education and a professor at the University of Ottawa. Berger, a reading specialist, is working at present with French and English research teams on pedagogical and assessment practices in literacy and numeracy. She is also part of the Ontario Minister of Education's Permanent Working Group.

Brock University, Volume 19, No. 2, Fall 2010, 48-64. 


\section{The Impact of Professional Development on Beginning Teachers' Practices in One Secondary School}

Professional development for beginning teachers from 1995-2006 in Ontario, Canada, was viewed by many policy makers and program developers as a means of improving teacher competencies, reducing the achievement gap among students in schools, and accelerating the implementation of reforms to the school curriculum.

In Canada, education is a provincial responsibility. In 1997, the Government of Ontario mandated the Ontario College of Teachers (College) to oversee the Teacher Professional Learning Program that required each teacher to complete 14 courses over five years. In addition, beginning teachers were required to take the Ontario Teacher Qualifying Test before they were eligible to be certified by the College.

The College in 2002 advocated a two-year induction program for newly-hired teachers. The program's goals were to improve teaching practices and thus student learning; to provide professional development opportunities; to contribute to a collaborative school environment; and to demonstrate to the public that new teachers have the skills and support they need to be effective teachers (Ontario College of Teachers [OCT], 2002, p.7). What do we know about beginning teachers and their professional development? What impact does professional development have on beginning teachers? To answer these questions, it is useful to first consult a growing body of literature.

\section{Background Literature}

Professional development for new teachers should begin with a solid induction program where they learn to consider specific educational contexts, and acquire practices and beliefs that last throughout their career (Glassford \& Salinitri, 2007; Luft, Roehrig, \& Patterson, 2003; Moir \& Gless, 2001; Wong \& Wong, 1998). Mentoring as an extension of an induction program, is needed to support teachers, provide them with feedback, and retain them in the profession of teaching (Ingersoll \& Kralik, 2004; Ingvarson, Meiers \& Beavis, 2005; Johnson, 2004). One of the benefits of mentoring can include beginning teachers identifying themselves with the profession (Healy \& Welchert, 1990). Research also indicates successful induction and mentoring programs: improve the quality of teaching, foster greater student achievement, facilitate the sharing of information about the professional work of the teacher and the daily job of classroom teaching, and help ensure new teachers are prepared and engaged in the educational process (Breaux \& Wong, 2003; Darling-Hammond \& Bradsford, 2005; Diaz-Maggioli, 2004; Fenwick, 2004; Hargreaves \& Fullan, 2000; McLaughlin \& Talbert, 2006).

Recent research indicates that beginning teachers differ from other teachers in their content knowledge and understanding of subject matter and application of learning to their teaching environment (Bransford, Brown, \& Cocking, 2000; Cochran-Smith, 2005; Fullan, Bertani, \& Quinn, 2004) and, therefore, require ongoing professional development and supervisory evaluations consistent with their stage/phase of development (Sergiovanni, 2007).

Beyond mentoring, teachers need professional development that focuses on subject content and pedagogical strategies and prompts them to make changes in their instructional practices (Garet, Porter, Desimone, \& Birman, 2001; Loucks-Horsley, Love, Stiles, Mundry \& 
Hewson, 2003). Growing evidence from large-scale studies also suggests beginning secondary school teachers require 60-80 hours of professional development to develop their knowledge and skills and enact standards-based instruction in their classrooms (Smith \& Ingersoll, 2004; Supovitz \& Turner, 2000).

Standards-based instruction can assist schools in establishing a culture of teacher reflection and self-assessment which contributes to new teachers' abilities to recognize mastery experiences and find gaps between desired and actual practices (Ross \& Bruce, 2007); it can also enable new teachers to become self-directed learners (Banilower, Boyd, Pasley \& Weiss, 2005) who can assess their progress. Bandura (1997) reminds us, however, that the psycho-social skills of interacting, perceiving, influencing and relating with and to others contribute heavily to beginning career success.

Effective supervision can also assist beginning teachers to adapt and to become active participants in the school's culture (Wood, 2005), and, using the Standards of Practice for the Profession that reflect a teacher's stage of development, can make it possible for a teacher to set goals, improve capacities for self-reflection, and internalize the expectations of the profession (Ontario Secondary School Teachers Federation [OSSTF], 2004).

Little is known about the efficacy of professional development programs for beginning teachers (Yoon, Duncan, Lee, Scarloss, \& Shapley, 2007) and its impact on their practices. These teacher practices include an understanding of the needs of their students, gaining and using subject content knowledge, and implementing sound instructional and classroom management strategies. In addition, teacher practices also focus on applying Special Education principles to students who have Individual Education Plans, integrating technology into the curriculum, using new student assessment and evaluations, contributing to innovative programs or projects, and collaborating with their colleagues (OCT, 1999).

To verify the impact of professional development on teachers' practices, Guskey (2005) suggests collecting and analyzing five critical levels of information: 1) participants' reactions to the professional development, 2) participants' gains in new knowledge and/or skills, 3) organizational support and change, 4) participants' use of new knowledge and skills, and 5) the impact on student outcomes.

To improve the quality and effectiveness of professional development programs, qualitative research that examines beginning teacher and administrative narratives of their reflections and assessments of the impact of professional development in progress needs to find a place in the literature (Cochrane-Smith, 2006; Leithwood, Seashore-Louis, Anderson \& Wahlstrom, 2004).

\section{Research Questions and Theory}

In order to obtain a better understanding of teachers' perspectives the following four research questions and theory framework were employed:

1. How do beginning teachers understand the definition and function of professional development?

2. How do the existing design and implementation of professional development contribute to beginning teachers' existing practices?

3. What goals and aspirations do beginning teachers have for professional development and how might these contribute to teachers' practices? 
4. Are the school board's goals and aspirations for the design and implementation of professional development in conflict with or congruent with the goals held by beginning teachers?

By examining the perspectives of teachers and administrators on professional development within the political and organizational context of one school and school board, the study presented current insights into the state of professional development. The authors, building upon the works of previous researchers, chose the following set of principles and theories to frame the inquiry: a) the principles of andragogy that focus on self-directed learning and application of that learning (Knowles, 1984, 1990); b) the theory of self-efficacy, which refers to "people's beliefs about their capabilities to produce designated levels of performance that exercise influence over events that affect their lives" (Bandura, 1994, p.71); c) the theory of collective efficacy, which "for schools, refers to the judgments of teachers in that school that the faculty as a whole can organize and execute the courses of action required to have a positive effect on students" (Goddard, 2004, p.4); and d) the theory of re-defined supervision that suggests professional development is a joint responsibility and that supervision be used to promote teacher development and build a professional community (Sergiovanni \& Starratt, 2002). The theoretical framework formed by these principles and theories proved useful in developing instruments and guiding the analysis of the investigation.

\section{Purpose and Method}

The case study outlined here was part of a larger research project that focused on three groups of teachers (beginning, mid-career, and experienced) and their ongoing experiences with professional development within one Ontario secondary school, Grades 7-12 (Hinds, 2007). The study also included interviewing three administrators on the subject of teacher professional development. Their interviews provided a basis for comparison between teacher and administrator perceptions on many issues pertaining to professional development activities and programs and opportunities to learn. The purpose of the study was to understand the meaning and purpose that each group of teachers attached to their ongoing professional development experiences and to describe and interpret how these experiences affected teachers' practices. The goals were to uncover the discernible interaction of factors characteristic of professional development, to gain insights into the relationship between effective professional development and improvement in practices for each group of teachers, and to learn how to recognize patterns that support and /or undermine teacher learning. This paper focuses solely on beginning teachers and their administrators.

\section{Demographic and Context Information}

Seventeen new teachers were hired by the school board (hiring and placement are the jurisdiction of the board, subject to the Collective Agreement and in accordance with the Acts and Regulations of the Province of Ontario) and assigned to a medium sized secondary school in 2004; of these, six were beginning teachers. The six beginning teachers and the three administrators in this study were part of an ethnically diverse teaching staff of 90 , and worked in a three year old school located in a modern middle class suburb of Ontario. The school's enrolment included 580 Grade 7-8 students who were situated in a separate section of the school 
and followed a different schedule from the 820 Grade 9-12 students. Ninety-six percent of the students were Caucasian. The visible minorities were students of Black and Asian descent.

Administrators and teachers spoke positively about the school's attendance record, accomplishments in sports, academics, community involvement, and the handling crisis situations; yet, there were strained relationships on a number of levels.

Of the six beginning teachers in this study, two were female teachers and four were male teachers. One male and one female teacher were assigned to the Gr. 7-8 division, one male teacher to the Gr. 7-12 division, and two male and one female teacher to the 9-12 division. Of these six teachers, three were teaching outside of their area(s) of training, and two were trained in a different province or country from Ontario, Canada (see Table 1, Appendix).

The professional development framework from the board that was in existence for beginning teachers in 2004 included a two-day orientation session, a series of workshops conducted primarily at the board by consultants, and activities available on a first-come firstserve basis. At the school level, professional development included administrator assistance in the formulation and feedback on the Teacher Annual Plan and the Teacher Performance Appraisal Program, department head led workshops during staff meetings once a month on literacy and student assessment, and 'just in time' professional development for report cards and parent-teacher meetings.

\section{Qualitative Inquiry}

The qualitative inquiry movement is built on a profound concern with understanding what other human beings are doing and saying (Schwandt, 2000). A case study, as Stake (2005) tells us is defined by an interest in the individual case 'beginning teachers' and not by the methods of inquiry used (p.443). One of the advantages of using a case study design is that problems and programs in their natural setting can be examined to bring about understanding that in turn can affect and perhaps even improve practice (Merriam, 1998). This study used an ethnographic approach in that the researchers weighed and categorized teacher and administrator experiences, made choices regarding what to include and what to exclude. This approach is not simply a chronicle but rather teacher and administrator interview scripts and researcher observations placed in a meaningful context of practices and histories (Richardson, 1990, p.10).

Voluntary engagement in the research project and protection of participants' confidentiality were in keeping with the Ethical Guidelines of the authors' home university and the criteria for research in schools. This qualitative research incorporated a number of data gathering measures: hour-long audio taped interviews with teachers and administrators, nontaped follow-up interviews, researcher field note observations, and the use of school and teacher artifacts and documents pertaining to professional development. Data were collected on a daily basis over a period of seven consecutive months. A transcription of each interview was returned to the participant to solicit feedback on content accuracy. Requests by teachers and administrators for modifications to their individual transcripts were accommodated.

\section{Data Analysis and Validation of the Study}

To facilitate the analysis process of the data from the interview and follow-up sessions, Nvivo 2.0 software was used. Seven steps suggested by Auerbach and Silverstein (2003) were employed to code the data: raw text, relevant text, repeated ideas, themes, constructs, narrative, 
and researcher's concerns. To validate the study, three strategies were employed: 1) Triangulation provided for confirmation and completeness of data. The multiple sources of data were derived from school board literature, school artifacts and documents pertaining to teacher professional development, and teacher and administrator interviews; 2) Participant validation was attained through feedback on transcriptions from beginning teachers and administrators through two independent researchers coding samples of the research, and through completion of an individual validation form. All six beginning teachers and administrators completed all of the phases on the research process; 3) Dependability was achieved by an audit trail which consisted of coded transcriptions and field notes.

\section{Study Findings}

\section{Conceptualizing Professional Development}

Teachers' conceptualization of professional development, its effects on their practices, their aspirations for professional development and their perceptions of the congruency of the school board and beginning teacher professional development are presented first; administrators' perceptions follow those of the teachers. Quotations from teacher and administrator interviews are identified by code initials and dates.

The sample of secondary school teachers and administrators interviewed for the study shared a complementary understanding regarding the theoretical meaning and educational function of professional development. Three of the six teachers defined professional development in terms of improving themselves. The other three teachers perceived professional development in socio-political as well as in school cultural terms. One teacher stated, "The purpose of PD is to become a better teacher in your subject area" (RD, 1/20/05). Another teacher related, "Professional development is meeting other Math teachers, sharing ideas and being able to, as professionals, meet and learn more from each other" (FH,12/14/04). A third teacher linked professional development to academic excellence and suggested that professional development set up by the school or the board had student achievement as the first priority but the by-product was teacher personal growth (CY, 12/3 \& 13/04). A fourth teacher remarked that the client base of the school was high, and this enabled the school to keep the teaching standards high. He added that "the rankings and ratings of the students' successes in the various testing program is a source of pride for the school, and administration ranks academic success high on the list of priorities" (LR, 11/26/04).

The three administrators understood the purpose of professional development as "an institutional goal to change teachers' practices and improve student achievement" (MY, 11/24/04); as "a means of developing teacher capacity" (EY, 11/25/04); and as "a strategic means of building in-house expertise" (ZI, 11/23/04).

\section{Contributions of Professional Development to Teachers' Classroom Practices}

The core categories that emerged from the data indicated that professional development by department heads, the literacy program, and professional development by teachers and administrators contributed to teachers' practices. 


\section{Department Head Led Professional Development}

Three teachers who were working in their subject area of specialization noted that department heads who were supervising their own specialty subject area assisted them with prioritizing the vast amount of content to be covered and with aligning the content to student assessment. One teacher noted that "Once I understood how to organize by big ideas, I was able to help some students change their attitude and explore the power of math as opposed to just using the tools" (FH, 11/24/04). Two other teachers recalled one department head who, through her ability to share resources and facilitate discussions, made a difference in their ability to bring consistency to their assessment practices, and differentiate instruction for students (CY, / 2/28/05; RD, 1/20/04).

\section{Literacy Program}

All six teachers said they found that the literacy program made a contribution to their teaching practices and believed that the collective effort at the school by staff, students and administration improved the reading scores at the school. One teacher stated that "Each department presents a section of Think Literacy Grades 7-12 to the whole staff and reviews the teaching strategies and best practices; the goal here is better literacy" (CY, 9/28/05).

Three teachers substantiated the value of literacy training to their practices by stating how they transferred skills reinforced in the literacy program to their respective subject areas: scanning for signal words helped students with complex math problems; using concept maps to generate and sort ideas in biology; and finding the main and supporting ideas in history classes. The two remaining teachers mentioned that the literacy program allowed teachers to question certain practices and collaborate as a group.

\section{Teacher and Administrator Led Professional Development}

The teachers acknowledged that their school environment was an extremely busy one. One teacher, who at an administrator's request provided in-service workshops for the staff on a software program for report cards, indicated that the experience gave him greater acceptance in the school culture and a sense of satisfaction knowing that teachers were using the program in their classrooms (FH, 9/26/05). Four teachers said they were thankful for the report card inservice and tips on parent interviews from administrators.

Administrators perceived the beginning teachers as highly skilled, capable, and focused on the curriculum. One administrator complained that the attitude of beginning teachers is, "if kids don't cut it, they don't cut it.... Personal growth should translate to the academic and social growth of their students" (ZI, 10/11/05). A second administrator described the literacy program as a grass roots initiative that was supported with funding from the Ontario Ministry of Education and Training (ministry). He elaborated, "The change in results of moving from a score of $70 \%$ to $93 \%$ on the EQAO [Education Quality and Accountability Office] test in reading is evidence that we are on the right track" (MY, 2/8/05). The third administrator described the pre/post test carried out before the literacy program and assessments to identify students at risk as types of data that beginning teachers used. She added, "Beginning teachers are open to professional development but changes in practices may not be readily discernible" (EY, 2/8/05). 


\section{Goals and Aspirations of Beginning Teachers}

Teachers hoped for some control over their own learning. Their individual priorities differed from each other, but, as a group, they valued accessing trained mentors, subject content knowledge and resources, and having a workload that factored in time for collaboration. Unlike administrators who envisioned full control over professional development from the board and professional development that was embedded in the teachers' practices at school, teachers sought professional learning both in and out of school to guide their growth and development

\section{Trained Mentors}

Four of the six teachers said they expected mentors to be trained and to follow a program that could be modified to address individual beginning teachers' needs for content or pedagogical knowledge, could ease their transition into the profession of teaching, could orient them to the system, and could provide them with assistance and support as they carried out their responsibilities. As one teacher pointed out, "Mentorship is part of the procedure here. The only thing is the individuals are chosen not necessarily because of their strengths but because they are willing to help" (ET, 12, 23, 2004). A second teacher stated, "I don't have a mentor; I wish I did" (RD, 12/14/04).

\section{Subject Content Knowledge and Resources}

The teachers envisaged a future where beginning teachers would not have to teach outside of their specialization, or, if they did, they would receive ongoing assistance in building their knowledge and instructional repertoire. Three of the six beginning teachers received teaching assignments "out-of-field," that is, they had less than a minor in the field in which they were teaching. One teacher stated, "My area of specialization is English and religion, but I am teaching science and math" (RD/1/20/05) A second teacher confided, "In my first three years of teaching, I taught 16 different subjects in six semesters" (LR, 12/16/04). A third teacher noted, “ I would like to get some professional development in the fields that I am teaching that I don't have much content knowledge or specific training on how to teach those subjects" (CY, 9/28/05).

The other three teachers said they envisaged orientation session for teachers hired late in the season, adequate supplies and materials, current math texts, teaching materials that they did not have to translate into French, funds for teachers to manage their own professional development, and pay for performance instead of pay for seniority.

\section{Time and Workload}

Six teachers identified time embedded in the work day, an increase in the number of Professional Development Days, and the use of those days, as elements that were missing from their present professional development agenda.

Five teachers believed that with more embedded professional development time they could address matters such as, collaborating on lesson plans, examining student work, analyzing data from tests, sharing classroom management strategies, and integrating technology into the curriculum. "Receiving .5 day leave to attend a training seminar on classroom management and a .5 day follow-up session was far from the support I need," stated one teacher (ET, 4/5/05). 
"What we need is time to express concerns and to dialogue with other teachers in the same subject area, same department, or same grade level," proposed another teacher (BE/1/25/05). The six teachers believed it was critical that professional development time allocated by the ministry not be used for changing semesters, inviting inspirational speakers, or planning community celebrations.

One teacher described the Grade 7-8 workload as 'unreal' because Grade 9-12 teachers had more prep time, could concentrate on one or two subjects, and saw far fewer students per day than did Grade 7-8 teachers. He used the term 'second class citizens' to describe their situation and noted that "Greater equity in workload and working conditions would positively affect teacher morale and create better learning conditions for students" (ET, 4/5/05).

Meeting the needs of all students was extremely difficult as one teacher explained, "I have twenty-three students in this class, and nineteen have had an Individual Education Plan" (LR, 10/3/05). The teacher expressed concerns that the learning environment was sometimes unsafe and unproductive. This teacher expressed the need for administrators to take a leadership role in addressing this issue at the board.

A second teacher, in taking on the role of curriculum leader after having just one year's experience in the profession, related that "There is no professional development on how to be a curriculum leader. It's hard to help others when you are learning yourself" (BE, 10/14/05).

One administrator, noting beginning teachers' aspirations and the lack of support to address their concerns, stated that "PD tends to be general in nature and focused on literacy or assessment and evaluation... Very rarely do they get PD that is particular to their own field.... and with our workload there is no time to meet the many needs" (EY, 11/25/04). A second administrator believed professional development should be self-directed as long as people recognized what they needed and where they wanted to go (ZI, 1/25/05).

\section{Congruence between Teacher and Board Goals for Professional Development}

Beginning teachers learned of board policy primarily through their colleagues or family members in the teaching profession. One teacher, recalling the signing of the teaching contract, stated, "When I went to the board and signed my papers, they never talked to me about professional development. Also, the school never mentioned it" (BE, 1/25/05). This teacher indicated that it was 'the old boys' network that had access to information on the best workshops and conferences that were partly subsidized by the school board. A second teacher stated, "The board and school expect a lot from us...it would be nice if we were allowed to talk sometimes .... I want to have a role in determining what I want to do better" (RD, 11/22/04).

\section{School Board Policy Issues}

Teachers perceived the professional development sessions in school, as well as time planned for beginning teachers away from school, as unrealistic. They also suggested that professional development provided by the school board was designed to satisfy a legal requirement. One teacher contended that taking off two days in the second week of school or meeting the week before report cards were examples of poor planning (FH, 11/26/04). Three of the teachers expressed the view that professional development had to take into consideration the needs and interest of teachers who aim to improve student learning in all subject areas. 
Perceptions of visits by school board consultants varied. One teacher commented that "He [the consultant] didn't say how to put it [the assessment and evaluation] into practice... That left huge gaps [in knowledge] in implementing the policy" (BE, 1/25/05).

\section{Relationships and Communications}

Four of the teachers believed that greater harmony in relationships between the school and the school board could provide a coherent approach to professional development. All six teachers experienced some degree of information overload and believed that devising a mechanism for streamlining the multiple communications from various sources intended for them would help them deal more effectively with what really mattered: their students' and their own growth and development.

The three administrators reinforced the idea that the school board needed to negotiate with the ministry for increased time, support, and resources for beginning teachers' professional development. One administrator identified three problems areas where the board and the school's professional development practices were incongruent 1) a reduction in the number of department heads and the amalgamation of departments; 2) teachers with minimum teaching experience becoming vice-principals and required to do Teacher Performance Appraisals; and 3) the allocation of money and resources to EQAO testing. "The whole crux of the problem," noted this administrator, "is political in nature and what they [the school board and the ministry] say we are getting and what is really happening are two different things" (MY, 10/11/05). This same administrator said, "There's little money in the budget for PD. It is not a priority for our board."

\section{Analysis of Challenges}

One possible explanation for the underlying dissatisfaction of beginning teachers and their administrators with professional development during 2004-2005 was a network of provincial government education reforms that had wide-reaching effects on teachers and their practices. This analysis and interpretation of the findings, while not absolving teachers of all responsibility for the advancement of their own learning, suggest that problems for the advancement of teacher learning and its application to practices often fell within the wider political and social realm. We are referring to changes to policies to education brought about by changes in government and changes in society: the family unit, economic means, attitudes toward authority, and technological impact on teaching.

Reforms that directly or indirectly affected beginning teachers' professional development and practices included: a) a centrally defined curriculum and a new report card; $b$ ) an increase in the number of courses taught and mandatory participation in extra-curricular activities; and c ) EQAO testing in Grade 9 in reading, writing and mathematics, and a literacy test for Grade 10 students.

The lack of coherence among reform policies, the lack of agreed upon vision of the board and the school, and the lack of sustained support with resources from the ministry left the board and the school pondering the purpose of teacher professional development and questioning the objectives of professional development programs. Based on teachers' responses to the research questions the reforms did affect their professional development and their practices. 


\section{System Approach}

The system approach to professional development is presented here as a key determinant that facilitated some types of professional development for teachers and hindered others. Beginning in 1995, with some reforms taking place in 1996, the provincial government by 1997 exercised its legal jurisdiction and authority to centralize education. By 2004, the provincial government controlled educational finances and was spending \$15 million annually on the Ontario Secondary School Literacy Test while at the same time delaying the release of over $\$ 100$ million for special needs students.

The prescriptive curriculum meant that groups of students and teachers were marginalized and their programs undervalued. The system approach to teachers' marking papers to establish consistency and programs that focused on testing did foster team work. The design and implementation of the professional development at the school and school board, however, was not a substitute for the day-to-day professional conversations that teachers in the study suggested they needed for subject content, instructional strategies, mapping the curriculum, joint lesson planning, classroom management, problem solving, and creating meaning for their practices.

\section{Teacher Identity}

In 1996 the government gave the College the authority to govern the province's teaching profession. By 2004 the conflict between the College and the teacher federations affected teacher identity; it prevented many new teachers from receiving the guidance they needed from these organizations that set standards and guidelines for the profession and have the responsibility to safeguard the quality of public education.

The number of courses taught by each Grade 9-12 teacher and the mandated extra curricular activities resulted in beginning teachers' not having the time to dialogue, work with mentors and colleagues, and demonstrate instructional strategies and classroom management techniques. The added component of mandating beginning teachers to take on extra-curricular activities meant these teachers were over-extended and were now exhibiting resentment toward other teachers who had a lighter load to bear.

\section{Support}

The provincial government's removal of $\$ 1$ billion from the education budget; the reduction in professional development days from nine to four; the increased supervision, program and management responsibilities assigned to principals and vice-principals; the reduction in leadership roles of department heads and consultants; and the mandate that teachers teach four credit classes a day adversely affected the organizational support that school boards and schools could offer beginning teachers.

Educational policy and related funding are key elements in teacher and student learning; the operating budgets and program infrastructure have a large impact on professional development opportunities and the options offered to teachers and administrators. The board as a result of the government's removal of dollars did not guarantee the school funds for teacher professional development. This state of affairs with professional development left teachers competing with one another for professional development places and left most dissatisfied with 
the process. Hence, this low level support for beginning teachers resulted in uneven progress in teacher knowledge, pedagogical strategies, practices and transition into the profession. This was evident in the study from the comments of teachers who were teaching in their subject areas and those who had been assigned to areas outside of their specialty.

\section{Implications and Recommendations}

Growing evidence suggests that training alone cannot meet the learning needs of beginning teachers. Professional development, to have a greater impact on beginning teacher practices, needs to be a focus on teacher learning and teacher capacity building which will give teachers expanded options to improve student learning and be part of a professional learning community. This change in focus will require commitment and purposeful support from all stakeholders.

High expectations for beginning teachers require a new model of professional development that must be met with a high level of support. The model which includes adult learning principles, self-efficacy, collective efficacy, and re-defined supervision requires a learning climate that involves beginning teachers in all phases: planning, implementation, and evaluation of their professional development and support in carrying out their objectives so they develop their skills of critical reflection. Those principles of adult learning could be used to bridge the gap between theory and practice and produce teachers who, because of their own learning experiences, have greater self-efficacy in the form of confidence, and provide better experiences for their students.

The model employs collective efficacy because the sense of group capability helps establish expectations for success that encourage members to work toward the desired end of establishing a workplace where teachers not only have a thorough knowledge of a subject area, help students relate ideas to one another, address misconceptions, and relate knowledge to everyday life but also are committed to school-community partnerships.

New understandings about professionalism, teaching and learning, and leadership suggest that supervision, the last component of the model, should be viewed as a joint responsibility with supervisors providing teachers with the opportunities and the resources they need and with teachers reflecting on their practices and sharing their best practices with others. The implication here is that the feedback from supervisors articulated in terms of teachers' and administrators' understandings of the teaching-learning process becomes a form of professional development that should positively impact on teachers' practices.

Various stakeholders, policy makers, Faculties of Education, school boards, administrators and teachers working together must be change agents in their respective areas. These stakeholders need to use a common language to agree upon the direction and scope of the change and to stay focused on the goal of achieving better professional development for beginning teachers.

Policy makers, using findings from research, could create a coherent support system for schools and develop mechanisms that ensure beginning teachers teaching outside of their subject area receive 60+ hours of professional development to acquire the subject knowledge and instructional skills that are essential to their classroom effectiveness.

Faculties of Education, using beginning teachers' comments that make visible what learning has been internalized and what has been imbedded into their practices, could make strategic decisions to expand programs to include features such as classroom management and teachers' transitions to the workplaces. 
School boards, working to change beginning teacher professional development, could require providers of professional development to have recent classroom experience and to know how to apply the principles of adult learning to the professional development sessions. Boards could work closely with schools to avoid duplication of professional development content and to find the 'best times' for beginning teachers' in-service.

Administrators, through a staff analysis, must ensure that beginning teachers do not receive the most difficult assignments. They need to find ways to hire workers to cover mentor-teacher non-teaching duties. In that way, beginning teachers and their mentors can conference 2-3 times per week or discuss with other colleagues strategies that promote their own and student learning.

Beginning teachers need to understand school board and school policies pertaining to professional development, seek guidance from colleagues, administrators, and consultants, and register the form of assistance received. They should also develop the practice of logging their learning from professional development and find venues to articulate its application to the classroom. 


\section{References}

Auerbach, C., \& Silverstein, L. (2003). Qualitative data: An Introduction to coding and analysis. New York: New York University Press.

Bandura, A. (1994). Self-Efficacy. In V. S. Ramachaudran (Ed.), Encyclopedia of Human Behavior (Vol. 4, pp. 71-81). New York: Academic Press.

Bandura, A. (1997). Self-efficacy: The exercise of control. New York: Freeman.

Banilower, E., Boyd, S., Pasley, J., \& Weiss, I. (2005). Lessons from a decade of mathematics and science reform: A capstone report for the local systemic change through teacher enhancement initiative. Chapel Hill, NC: Horizon Research, Inc.

Bransford, J., Brown, A., \& Cocking, R. (2000). How people learn: Brain, mind, experience, and School (Expanded edition). Washington: National Academy Press.

Breaux, A., \& Wong, H. (2003). New teacher induction: How to train, support, and retain new teachers. Mountain View, CA: Harry K. Wong Publications.

Cochran-Smith, M. (2005). Teacher Education and the outcome trap. Journal of Teacher Education, 56(5), 411-417.

Cochran-Smith, M. (2006). Policy, practice, and politics in education. Thousand Oaks: Corwin Press.

Darling-Hammond, L., \& Bradsford, J. (2005). Preparing teachers for a changing world: What teachers should learn and be able to do. San Francisco: Jossey-Bass.

Diaz-Maggioli, G. (2004). A passion for learning: Teacher-centered professional development. Alexandria, Virginia: ASCD. Educational Leadership, 61(7), 42-46.

Fenwick, T. (2004). Teacher learning and professional growth plans: Implementation policy. Journal of Curriculum \& Supervision, 259-282.

Fullan, M., Bertani, A., \& Quinn, J. (2004). New Lessons from Districtwide Reform. Educational Leadership. 61 (7) 42-46.

Garet, M., Porter, A., Desimone, L., \& Birman, B. (2001). What makes professional development effective: Analysis of a national sample of teachers. American Education Research Journal, 38(4), 915-945.

Glassford, L., \& Salinitri, G. (2007). Designing a successful new teacher induction program: An assessment of the Ontario program experience, 2003-2006. Canadian Journal of Education Administration and Policy (60).

Goddard, R. (2004). Collective efficacy: Theoretical developments, empirical evidence, and future directions. Educational Researcher, 33(3), 3-13. 
Guskey, T. (2005). A Conversation with Thomas Guskey. The Evaluation Exchange, X1(4).

Hargreaves, A., \& Fullan, M. (2000). Mentoring in the new millennium. Theory into Practice, $39(1), 55$.

Healy, C., \& Welchert, A. (1990). Mentoring relations: A definition to advance research and practice. Educational Researcher, 19(1), 17-21.

Hinds, M. (2007). A case study: teacher professional development and its impact on the improvement of practice in one Ontario secondary school. Unpublished doctoral dissertation, Ottawa University, Ontario.

Ingersoll, R., \& Kralik, J. (2004). The impact of mentoring on teacher retention: What research says. Denver, CO: Education Commission of the States.

Ingvarson, L., Meiers, M., \& Beavis, A. (2005). Factors affecting the impact of professional development programs on teachers' knowledge, practice, student outcomes \& efficiency. Education Policy Analysis Archives, 13(10).

Johnson, S. (2004). Finders and keepers: Helping new teachers survive and thrive in our schools. San Francisco: Jossey-Bass

Knowles, M. (1984). The adult learner. A neglected species (3rd ed.). Houston: Gulf Publishing.

Knowles, M. (1990). The adult learner (4th ed.). Houston: Gulf Publishing.

Leithwood, K., Seashore Louis, K., Anderson, S., \& Wahlstrom, K. (2004). How leadership influences student learning. New York: The Wallace Foundation.

Loucks-Horsley, S., Love, N., Stiles, K., Mundry, S., \& Hewson, P. (2003). Designing professional development for teachers of science and mathematics $\left(2^{\text {nd }}\right.$ ed.). Thousand Oaks: Corwin Press, Inc.

Luft, J., Roehrig, G., \& Patterson, N. (2003). Contrasting landscapes: A comparison of the impact of different induction programs on beginning secondary science teachers' practices, beliefs, and experiences. Journal of Research in Science Teaching, 40 (1), 77 97.

McLaughlin, M. \& Talbert, J. (2006). Building school-based teacher learning communities: Professional strategies to improve student achievement. New York: Teachers College Press.

Merriam, S. (1998). Qualitative research and case study applications in education. Hoboken, NJ: Jossey-Bass.

Moir, E., \& Gless, J. (2001). Quality induction: An investment in teachers. Teacher Education Quarterly, 28(1), 109-114. 
Ontario College of Teachers (1999). Standards of practice for the teaching profession. [Online] Retrieved from http://www.oct.ca/home.aspx

Ontario College of Teachers (2002, March 17). Government Penalizes Ontario Teachers with Rushed Qualifying Test. [Media Release]. Retrieved from http://www.oct.ca/home/apex

Ontario Secondary School Teachers Federation/FEESO (2004). Review of the Standards of Practice for the Teaching Profession. Retrieved from http://www.osstf.on.ca

Richardson, L. (1990). Writing strategies: Reaching diverse audiences. Newbury Park, CA: Sage.

Ross, J., \& Bruce, C. (2007). Teacher self-assessment: A mechanism for facilitating professional growth. Teaching and Teacher Education, 23(2), 146-159.

Schwandt, T. (2000). Three epistemological stances for qualitative inquiry: Interpretivism, hermeneutics and social construction. In N. Denizen \& Y. Lincoln (Eds.). Handbook of qualitative research (pp.189-213). Thousand Oaks, CA: Sage.

Sergiovanni, T. (2007). Rethinking leadership: A collection of articles. Thousand Oaks, California: Corwin Press.

Sergiovanni, T. \& Starratt, R. (2002). Supervision: a redefinition (7th ed.). Boston: McGrawHill.

Smith, T. \& Ingersoll, R. (2004). What are the effects of induction and mentoring on beginning teacher turnover? American Educational Research Journal, 41(3).

Stake, R. (2005). Qualitative case studies. In N. Denzin and Y. Lincoln (Eds.). The Sage Handbook of Qualitative Research. Thousand Oaks, CA: Sage.

Supovitz, J., \& Turner, H. (2000). The effects of professional development on science teaching practices and classroom culture. Journal of Research in Science Teaching, 37(9), 963980 .

Wong, H. \& Wong, R. (1998). How to be an effective teacher: The first days of school. Mountainview, CA: Harry K. Wong Publications, Inc.

Wood, A. (2005). The importance of principals: Site administrators' role in novice teacher induction. American Secondary Education, 33 (2), 39-62.

Yoon, K.S., Duncan T., Lee, S. W.-Y., Scarloss, B., \& Shapley, K.L. (2007). Reviewing the evidence on how teacher professional development affects student achievement. (Issues \& Answers Report, REL, 2007, No. 033). Washington, DC: US Department of Education, Institute of Education Sciences, Regional Educational Laboratory Southwest. 


\section{Appendix}

Table 1: Demographic Information on Beginning Teachers and Administrators

\begin{tabular}{|c|c|c|c|c|}
\hline $\begin{array}{l}\text { Gender of } \\
\text { Participants }\end{array}$ & Division & $\begin{array}{l}\text { Teaching } \\
\text { Experience }\end{array}$ & $\begin{array}{l}\text { Teaching } \\
\text { Assignment }\end{array}$ & $\begin{array}{l}\text { Qualifications \& Added } \\
\text { Responsibilities }\end{array}$ \\
\hline 1 female & Gr. 7-8 & $3 \mathrm{yrs}$ & $\begin{array}{l}\text { Religion, English, } \\
\text { Science. }\end{array}$ & $\begin{array}{l}\text { B.A/B. Ed. (ON) } \\
\text { Curriculum Lead. } \\
\text { Areas of specialization } \\
\text { English/Religious Ed. }\end{array}$ \\
\hline 1 male & Gr. 7-8 & $\begin{array}{l}1 \mathrm{yr}+10 \\
\text { years High } \\
\text { Tech. } \\
\text { Business }\end{array}$ & $\begin{array}{l}\text { French, Math, } \\
\text { Science. }\end{array}$ & $\begin{array}{l}\text { B.A/B. Ed. (ON) } \\
\text { Math/French }\end{array}$ \\
\hline 1 male & Gr. 7-12 & 2 yrs. & $\begin{array}{l}\text { PhD, Religion, } \\
\text { History }\end{array}$ & $\begin{array}{l}\text { B.A/B. Ed. } \\
\text { Areas of specialization } \\
\text { History/geography }(\mathrm{BC})\end{array}$ \\
\hline 1 male & Gr. 9-12 & $2 \mathrm{yrs}$ & $\begin{array}{l}\text { Construction } \\
\text { Technology }\end{array}$ & $\begin{array}{l}\text { B. Ed } \\
\text { Areas of specialization } \\
\text { Economics /Bus. } \\
\text { Management/Design \& } \\
\text { Tech (AU) }\end{array}$ \\
\hline 1 male & Gr. 9-12 & $2 \mathrm{yrs}$ & $\begin{array}{l}\text { Math, } \\
\text { Technology, } \\
\text { English }\end{array}$ & $\begin{array}{l}\text { B. Ed/ B. Sc. }(\mathrm{ON}) \\
\text { Area of specialization } \\
\text { Science/Biology }\end{array}$ \\
\hline 1 female & Gr. 9-12 & 2 yrs. & $\begin{array}{l}\text { Math, Science, } \\
\text { English }\end{array}$ & $\begin{array}{l}\text { B.A/B. Ed.(ON) } \\
\text { Area of specialization } \\
\text { English/Religious } \\
\text { Studies }\end{array}$ \\
\hline Admin. & Supervision & $\begin{array}{l}\text { Teach/Admi } \\
\text { n. }\end{array}$ & & \\
\hline 1 male & Gr.9-12 & $11 / 15 \&$ & nil & M.PHE. \\
\hline 1 male & Gr. 9-12 & $12 / 6 \mathrm{yrs}$ & nil & M.Ed. \\
\hline 1 female & Gr.9-12 & $17 / 3$ yrs & nil & M. Sc. \\
\hline
\end{tabular}

